Bawden, F. C. \& Kleczkowski, A. (1955). J. gen. Microbiol. 13, 370-382

\title{
Studies on the Ability of Light to Counteract the Inactivating Action of Ultraviolet Radiation on Plant Viruses
}

\author{
By F. C. BAWDEN and A. KLECZKOWSKI \\ Rothamsted Experimental Station, Harpenden, Hertfordshire
}

SUMMARY: Of seven plant viruses tested, all except tobacco mosaic showed the phenomenon of photoreactivation, i.e. plants exposed to visible light after inoculation with preparations partially inactivated by ultraviolet radiation produced more local lesions than plants kept in darkness. Five strains of tobacco mosaic virus, which differed widely in their pathogenicity and other properties, were tested, but none showed the phenomenon. Of the six viruses that did, potato $\mathrm{X}$ showed it much the most strongly, tomato bushy stunt and a tobacco necrosis virus the least; cabbage black ringspot, cucumber mosaic and tobacco ringspot were intermediate.

Photoreactivation does not occur immediately after plants are inoculated. With irradiated preparations of potato virus $X$, most particles need about $30 \mathrm{~min}$. to reach the state in which their ability to infect is affected by light; once in this state, exposure to daylight for $15 \mathrm{~min}$. gives almost complete photoreactivation. Some irradiated particles respond to light of 80 f.c., but others need brighter light; no additional response occurs when light intensity is increased above 600 f.c. The sensitive state of potato virus $X$ persists for about $1 \mathrm{hr}$. in plants kept in darkness, after which the particles seem to be permanently inactivated.

With antibodies and enzymes, a constant amount of absorbed energy decreases the activity of a unit weight by a given fraction. This rule does not apply to plant viruses, which lose infectivity with less absorbed energy than the rule predicts. If viruses are more sensitive because they contain nucleic acid, their sensitivity is not a direct function of their content of nucleic acid. Potato virus $\mathrm{X}$ has the same nucleic acid content as strains of tobacco mosaic virus, but is inactivated by less absorbed energy and individual strains of tobacco mosaic virus also differ by factors of two in the amount of radiation needed to decrease their infectivity by a given fraction.

Visible light mitigates the damaging effects that ultraviolet radiation has on many kinds of cells (Kelner, 1949, 1951; Bawden \& Kleczkowski, 1952). It can also partially restore the activity of irradiated preparations of some viruses; exposure of the irradiated viruses to light in vitro has no effect on their ability to multiply, but more of the irradiated particles multiply when recently infected cells are exposed to light than when they are kept in darkness (Dulbecco, 1950; Bawden \& Kleczkowski, 1953). The alleviating effect of visible light both on irradiated cells (Kelner, 1949) and bacterial viruses (Dulbecco, 1950) has been called 'photoreactivation', and for simplicity and uniformity we shall also use this term. However, we stress the fact that there is no evidence to show whether the phenomenon occurs because changes caused in virus particles by the radiation are reversed in illuminated cells, or because conditions in such cells favour infection and allow damaged particles to multiply.

Of the three viruses we studied earlier, tomato bushy stunt and the Rothamsted tobacco necrosis virus showed the phenomenon of photoreactivation, and 
tobacco mosaic virus did not (Bawden \& Kleczkowski, 1953). As the same host plant (Nicotiana glutinosa) was used for tests with tomato bushy stunt and tobacco mosaic viruses, it seemed that the ability to respond to visible light was an intrinsic property of individual viruses and was not determined by the identity of the host. Tomato bushy stunt and the tobacco necrosis virus resemble one another in many respects; both have spherical particles containing about $18 \%$ nucleic acid and have small temperature coefficients of thermal inactivation, whereas tobacco mosaic virus has elongated particles, only a third as much nucleic acid and a large coefficient of thermal inactivation. To see how general photoreactivation is with plant viruses and whether its occurrence can be correlated with any other properties, such as shape or gross composition, we have now studied four other viruses and four additional strains of tobacco mosaic virus. For these experiments we were restricted to viruses that occur in relatively high concentration in expressed sap and produce countable local lesions, but within these limitations we made a choice with as wide a range of characters as possible. Potato virus $\mathbf{X}$ has the same nucleic acid content as tobacco mosaic and behaves in the same manner when heated; it differs in being hydrolysed by proteases and its elongated particles are thinner and more flexible. Cabbage black ringspot virus has particles morphologically similar to those of potato virus $\mathbf{X}$; their content of nucleic acid is unknown. The spherical particles of tobacco ringspot virus are about the same size as those of tomato bushy stunt but contain more nucleic acid. Cucumber mosaic virus, which is also probably spherical, has a small temperature coefficient of thermal inactivation; its content of nucleic acid is unknown.

Photoreactivation was not detectable with any of the strains of tobacco mosaic virus, but the other viruses all showed it to a greater extent than did tomato bushy stunt or the tobacco necrosis virus, and potato $\mathbf{X}$, despite its many similarities to tobacco mosaic virus, showed it far more strongly than any other. Thus we were unable to correlate the phenomenon with other known distinguishing features of plant viruses. The viruses which show it are so diverse that photoreactivation is almost certainly usual rather than exceptional, although it would be premature to assume that tobacco mosaic virus is a unique exception. As the phenomenon seems to be general, and potato virus $\mathbf{X}$ provided such a convenient test object for studying details of the process, the main purpose of our work was changed to find out more about the conditions in which visible light permits the multiplication of virus particles after they have been altered by ultraviolet radiation.

\section{MATERIALS AND METHODS}

The five strains of tobacco mosaic virus used were: (1) the Rothamsted stock culture; (2 and 3) U1 and U2 (Ginoza, Atkinson \& Wildman, 1954), which were kindly supplied by Dr S. G. Wildman; (4) one that causes a systemic mosaic in Datura stramonium and which we shall call the Datura strain; (5) tomato aucuba mosaic virus. The first four were propagated in tobacco (Nicotiana tabacum), U2 in Turkish, as it gives only necrotic local lesions in 
White Burley, and the others in White Burley; local-lesion tests were made with all four in Nicotiana glutinosa. Tomato aucuba mosaic virus was propagated in tomato (Lycopersicum esculentum, var. Kondine Red) and local-lesion tests were made with White Burley tobacco. White Burley tobacco was also used for local-lesion tests with the other four viruses, two of which, tobacco ringspot and cucumber mosaic were propagated in tobacco, the third, potato $\mathbf{X}$, in Nicotiana glutinosa, and cabbage black ringspot in turnip (Brassica napus).

Most of the experiments were made with clarified infective sap diluted in $\mathrm{M} / \mathbf{1 5}$-phosphate buffer $(\mathrm{pH} 7)$. The sap extracted from macerated leaves was clarified by freezing, thawing and centrifuging at 6000 r.p.m. Purified preparations of the strains of tobacco mosaic virus and of potato virus $\mathbf{X}$ were made by repeatedly precipitating the viruses at their isoelectric points or with $\left(\mathrm{NH}_{4}\right)_{2} \mathrm{SO}_{4}$, followed by sedimenting them from neutral solutions by centrifuging at 40,000 r.p.m. When preparations of the tobacco mosaic viruses were still coloured, the colour was removed by incubating them with citrate (Ginoza et al., 1954). The purified preparations were dialysed against distilled water and diluted in the buffer before being exposed to ultraviolet radiation.

Ultraviolet radiation was provided by a Vitreosil low-pressure mercury lamp, most of whose radiation is of wavelength $2537 \mathrm{~A}$. The fluids were irradiated as layers $0.14 \mathrm{~cm}$. deep in Petri dishes placed $20 \mathrm{~cm}$. from the lamp, where the intensity of the radiation was $870 \mu \mathrm{W}$./sq.cm. The dishes were rocked continually during the period of irradiation; this was assumed to have ensured that all particles were equally exposed.

The amount of radiation at wavelength $2537 \mathrm{~A}$. absorbed by fluids was measured with a quartz spectrophotometer.

The relative infectivities of different virus preparations were measured by counting local lesions. When the maximum accuracy was needed, irradiated and un-irradiated preparations at various dilutions were inoculated to half leaves, the different inocula being distributed in such a way that each occurred the same number of times on each plant and at each leaf position. After counting the lesions, a dilution curve was drawn by plotting the numbers of lesions produced by the un-irradiated virus preparation against the logarithm of its dilution. The residual infectivity of irradiated preparations was then obtained by graphic interpolation. When less accurate comparisons sufficed, irradiated and un-irradiated preparations were inoculated to opposite half leaves, after so adjusting the dilutions of the two that they could be expected to give approximately similar numbers of lesions: for instance, if the irradiation was expected to destroy $99 \%$ of infectivity, the irradiated preparation was inoculated 100 times as concentrated as the control.

Unless otherwise stated, all the plants used in any one experiment were treated uniformly before they were inoculated and, to increase their susceptibility to infection, they were usually kept in darkness for $\mathbf{2 4} \mathrm{hr}$. immediately before they were inoculated. Immediately after inoculation they were differentially treated, some being placed in daylight or artificial light and others in the dark for different periods. After $24 \mathrm{hr}$. all the plants were again returned to the ordinary daylight conditions of a glasshouse. 


\section{RESULTS}

\section{The photoreactivation of different viruses}

The course of inactivation by ultraviolet radiation of all viruses previously studied approximated closely to that of a first-order reaction, and this was so whether or not the inoculated plants were placed in the light (Bawden \& Kleczkowski, 1953). We have not made critical tests with the other viruses used in this work, but their inactivation also seems to approximate to a firstorder reaction. This being so, it can be assumed that the proportion, $p$, of the original infectivity that remains after a preparation has been irradiated for time $t$ will be given, at least approximately, by the equation $p=e^{-k t}$, in which $k$ is a constant. Using viruses that show the phenomenon of photoreactivation, $k$ will be greater when inoculated plants are placed in the dark than when they are placed in the light, and the ratio of the values obtained with plants in the two conditions will provide a measure of the extent of photoreactivation.

\section{Table 1. Relative amounts of photoreactivation with different viruses}

Virus $\quad k_{\text {dark }}^{*} \quad k_{\text {light }} \quad \frac{k_{\text {dark }}}{k_{\text {light }}} \quad \begin{gathered}\text { Kind of preparation } \\ \text { irradiated }\end{gathered}$

(1) Tobacco mosaic

(a) Stock strain

(b) Datura strain

(c) U1

(d) $\mathrm{U} 2$

(e) Tomato aucuba mosaic strain

(2) Tomato bushy stunt

(3) Rothamsted tobacco necrosis

(4) Cucumber mosaic

(5) Tobacco ringspot

(6) Cabbage black ringspot

(7) Potato $X$

\begin{tabular}{|c|c|}
\hline $1 \cdot 6$ & $1 \cdot 6$ \\
\hline $1 \cdot 6$ & $1 \cdot 6$ \\
\hline $1 \cdot 6$ & $1 \cdot 6$ \\
\hline $3 \cdot 3$ & $3 \cdot 3$ \\
\hline 0.7 & 0.7 \\
\hline- & - \\
\hline- & - \\
\hline $3 \cdot 2$ & $2 \cdot 1$ \\
\hline $3 \cdot 2$ & $1 \cdot 7$ \\
\hline $3 \cdot 0$ & $1 \cdot 5$ \\
\hline $2 \cdot 5$ & $0 \cdot 8$ \\
\hline
\end{tabular}

$\mathbf{0 . 0 2} \%$ solution of purified virus

Infective sap at $1 / 50$

-
Infective sap at $1 / 10$
Infective sap at $1 / 10$
Infective sap at $1 / 5$
Infective sap at $1 / 10$

* Value of $k$ was derived from $p=e^{-k t}$ where $p$ is the proportion of original infectivity remaining after irradiating for $t$ min.: $k_{\text {dark }}$ is value when plants were placed in the dark after inoculation and $k_{\text {light }}$ when placed in the light. A figure of more than 1 for $k_{\text {dark }} /$ $k_{\text {light }}$ indicates photoreactivation.

$\dagger$ Results obtained with purified viruses and already published (Bawden \& Kleczkowski, 1953).

Table 1 gives values for $k$, and for the ratios of $k_{\text {dark }} / k_{\text {light }}$, obtained from experiments with five strains of tobacco mosaic virus and with six other viruses. The strains of tobacco mosaic virus differ in their sensitivity to ultraviolet radiation, but all give a value of 1 for the ratio $k_{\text {dark }} / k_{\text {ligbt }}$, showing no detectable photoreactivation, whereas with all the other viruses the value is more than 1 and reaches 3 with potato virus $X$. The ratios in Table 1 are calculated from the results of single experiments and are to be regarded as convenient indications of the extent to which the different viruses can be photoreactivated rather than as exact measures, for the amount of photoreactivation given by one of the viruses in the same host varies from experiment to experiment. With potato virus $\mathbf{X}$, for example, the ratio is 
usually about 3 , but it has occasionally been as small as 2 . The extent of photoreactivation does not depend on the identity of the host plant, for the tomato aucuba strain of tobacco mosaic virus showed none in either Nicotiana glutinosa or tobacco, whereas potato virus $\mathrm{X}$ showed it as strongly in $N$. glutinosa as in tobacco.

We do not know what causes the quantitative variations in response in different experiments, but we suspect that the physiological condition of the plants at the time they are inoculated is important. When plants are placed in the dark for a day or more before they are inoculated, their susceptibility to infection increases, so that any inoculum produces more local lesions than when the plants have been kept under normal glasshouse conditions. Putting plants in the dark after they have been inoculated with tobacco mosaic, tomato bushy stunt or tobacco necrosis viruses, has little effect on the numbers of lesions produced by unirradiated inocula, usually decreasing them slightly (Bawden \& Roberts, 1948). Our experiments have confirmed these results with these three viruses, but have given different results with the other four. Putting tobacco plants in the dark for a day or so before they were inoculated always increased the numbers of lesions produced by a given inoculum, though the increase was sometimes small, but putting them in the dark after inoculation gave very variable results. Sometimes plants inoculated with un-irradiated preparations of potato $\mathbf{X}$, cucumber mosaic or tobacco ringspot virus, gave similar numbers of lesions in the light and dark, sometimes plants placed in the dark gave many more lesions than those in the light, and occasionally they gave many fewer. In all experiments to compare irradiated and un-irradiated preparations of these viruses, there was unequivocal evidence of photoreactivation with the irradiated inocula, but the ratio $k_{\text {dark }} / k_{\text {light }}$ varied with the effects of darkness on the numbers of lesions produced by the un-irradiated inocula.

At first sight the failure of strains of tobacco mosaic virus to show any photoreactivation suggests that ultraviolet radiation changes it differently from the others, but this is not a necessary conclusion. With those viruses that show the phenomenon, irradiation obviously produces at least two changes: one that allows particles to multiply only if the cells they infect are illuminated, and another that prevents them from multiplying even in these cells. There is no need to assume that the first change is an essential preliminary to the second; the two may be quite independent happenings. To detect the two, however, the one leading to photoreactivation must occur quicker than the change leading to full inactivation, and the greater the difference between the rates of the two changes, the more easy will the two be to detect. With tobacco mosaic virus, the two kinds of change may also occur, but the one that shows as photoreactivation with the other viruses may be undetectable because it happens only after virus particles have been inactivated. If this is so, however, the kind of change that leads to photoreactivation with other viruses occurs in tobacco mosaic virus only after very much more irradiation, for most of its strains resist inactivation by ultraviolet radiation more than do the other viruses. Ginoza et al. (1954) found that the strain U 2 is more readily inactivated than other strains tested and we have confirmed this: it shows in 
Table 1 by the greater value of $k$ obtained with purified preparations of this strain than with preparations of other strains, when irradiated at the same concentration. U2 has the same extinction coefficient, about $2 \cdot 75$, as the other strains.

The values of $k$ given in Table $\mathbf{I}$ for viruses irradiated in infective sap cannot be taken as indicating their relative susceptibility to inactivation, because their relative concentrations were unknown and other constituents of the sap also absorb ultraviolet radiation strongly; these other constituents occur in widely different amounts in different samples of sap from the same plant species. For comparing results with different viruses irradiated in infective sap, only the ratios $k_{\text {dark }} / k_{\text {light }}$ are significant as indicating the relative amounts of photoreactivation they give.

\section{Effect of different exposures to light on photoreactivation of potato virus $X$}

The experiments described so far were all made to find whether or not a given inoculum could be photoreactivated. In each one, the plants were treated uniformly before they were inoculated and immediately afterwards were placed either in the light or dark where they were kept continuously for at least $6 \mathrm{hr}$. The results provide no information on the details of the processes involved in photoreactivation, either about how it is affected by light intensity and the physiological state of plants when they are inoculated, or at what stage during the process of infection it occurs.

To study such details we chose potato virus $\mathbf{X}$ because it gives much the largest ratio of $k_{\text {dark }} / k_{\text {light }}$. The effects of irradiation in different experiments were kept as constant as possible by always using the same batch of sap from systemically infected Nicotiana glutinosa. The sap was divided into $5 \mathrm{ml}$. lots stored at $-30^{\circ}$, and a freshly thawed lot was used for each experiment. After centrifuging, the sap was diluted $1 / 10$ with $\mathrm{m} / 15$-phosphate buffer $(\mathrm{pH} 7)$, when it was centrifuged again to remove the precipitate that formed. The clear fluid was then irradiated for $3 \mathrm{~min}$., diluted with an equal volume of the buffer and used as inoculum. This exposure to ultraviolet radiation decreased the infectivity to about $0.05 \%$ that of the original fluid when inoculated plants were placed in the dark and to about $5 \%$ when they were placed in the light for the $6 \mathrm{hr}$. after inoculation. So that the un-irradiated control should give reasonably comparable numbers of lesions, the sap diluted 1/10 was diluted a further $1 / 200$ with the buffer before using it as an inoculum. The irradiated inoculum then usually produced more lesions than the un-irradiated on plants kept in the light and fewer on those kept in the dark. The two inocula were rubbed over the opposite halves of the same leaves, three leaves on each of three plants being used for each comparison. The ratios of the numbers of local lesions conveniently indicate the relative infectivities of the two inocula, but they are not exact measures of their relative contents of infective virus because numbers of local lesions are not directly proportional to the concentration of infective particles.

To see whether photoreactivation is affected by the metabolism of the plants immediately before they are inoculated, batches of plants were divided into 
two groups, one of which was kept in the dark for the $48 \mathrm{hr}$. before the plants they were inoculated and the other continuously in light, namely daylight supplemented by $\mathbf{5 0 0}$ f.c. of artificial light during the two nights. After rubbing opposite half leaves with irradiated and un-irradiated inocula, half of the plants from each group were placed in daylight and half in the dark. Table 2 shows

Table 2. Photoreactivation unaffected by treatment of plants before inoculation

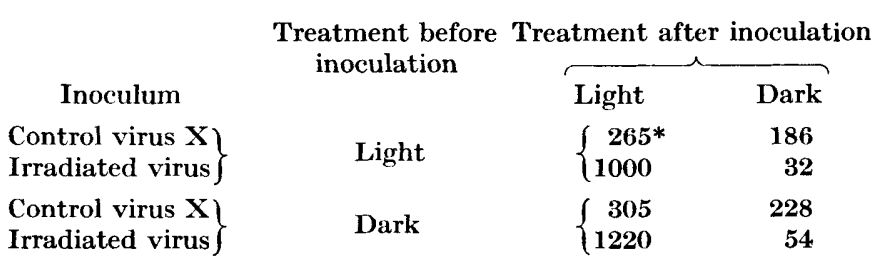

* Figures are the total number of lesions produced on nine half-leaves. Control inoculum was infective sap at $1 / 2000$; sap at $1 / 10$ was exposed to ultraviolet radiation for $3 \mathrm{~min}$., and then diluted $\frac{1}{2}$ before inoculating.

that, regardless of their previous treatment, approximately the same amount of photoreactivation was given by plants placed in the light after they were inoculated. Thus the phenomenon seems to depend on some almost immediate response to light by a host system and not on some stable intermediate product that is synthesized in the light and can persist in plants kept in the dark. The system operates equally readily whether it has previously been continuously active or inactive for long periods, and it is distinct from the system which increases the susceptibility of plants to infection with un-irradiated viruses when they are kept in the dark before inoculation.

Table 3. Photoreactivation of potato virus $X$ after keeping inoculated plants in darkness for different periods

\begin{tabular}{|c|c|c|c|}
\hline $\begin{array}{c}\text { The time in } \\
\text { darkness after } \\
\text { inoculation (hr.) }\end{array}$ & Inoculum & $\begin{array}{l}\text { Total nos. of } \\
\text { lesions on nine } \\
\text { half-leaves }\end{array}$ & $\begin{array}{c}\text { Ratio: } \\
\text { irradiated/control }\end{array}$ \\
\hline 0 & $\left\{\begin{array}{l}\text { Control } \\
\text { Irradiated }\end{array}\right.$ & $\left.\begin{array}{l}269 \\
460\end{array}\right\}$ & $1 \cdot 7$ \\
\hline 1 & $\left\{\begin{array}{l}\text { Control } \\
\text { Irradiated }\end{array}\right.$ & $\left.\begin{array}{l}292 \\
406\end{array}\right\}$ & $1 \cdot 4$ \\
\hline 2 & $\left\{\begin{array}{l}\text { Control } \\
\text { Irradiated }\end{array}\right.$ & $\left.\begin{array}{l}425 \\
210\end{array}\right\}$ & 0.5 \\
\hline 3 & $\left\{\begin{array}{l}\text { Control } \\
\text { Irradiated }\end{array}\right.$ & $\left.\begin{array}{r}420 \\
88\end{array}\right\}$ & $0 \cdot 2$ \\
\hline 24 & $\left\{\begin{array}{l}\text { Control } \\
\text { Irradiated }\end{array}\right.$ & $\left.\begin{array}{r}317 \\
30\end{array}\right\}$ & $0 \cdot 1$ \\
\hline
\end{tabular}

Irradiated virus particles do not remain continuously in inoculated leaves in the state where their ability to infect is affected by visible light. Table 3 shows that $1 \mathrm{hr}$. in the dark after inoculation had little effect on the amount of photoreactivation that can be obtained, but a stay of $2 \mathrm{hr}$. greatly decreased it and after $3 \mathrm{hr}$. there was very little. 
Table 4 gives the results of an experiment to find how varying the length of exposure to daylight affects the amount of photoreactivation when the exposures were made at two different times, one immediately after the plants were inoculated and the other after spending a preliminary period of an hour in the dark. The fact that exposures of less than $1 \mathrm{hr}$. gave more photoreactivation after $1 \mathrm{hr}$. in the dark than immediately, suggests that the irradiated particles do not immediately become susceptible to the beneficial effects of light. Using the ratios of the numbers of lesions produced by the two inocula

\begin{tabular}{|c|c|c|c|}
\hline $\begin{array}{l}\text { Time of exposure to light } \\
\text { immediately after } \\
\text { inoculation }\end{array}$ & Inoculum & $\begin{array}{l}\text { Total nos. of lesions } \\
\text { on nine half-leaves }\end{array}$ & $\begin{array}{c}\text { Ratio: } \\
\text { irradiated/control }\end{array}$ \\
\hline 0 & $\left\{\begin{array}{l}\text { Control } \\
\text { Irradiated }\end{array}\right.$ & $\left.\begin{array}{r}1520 \\
547\end{array}\right\}$ & $0 \cdot 35$ \\
\hline $7 \frac{1}{2} \min$ & $\left\{\begin{array}{l}\text { Control } \\
\text { Irradiated }\end{array}\right.$ & $\left.\begin{array}{r}1600 \\
381\end{array}\right\}$ & $0 \cdot 25$ \\
\hline $15 \mathrm{~min}$. & $\left\{\begin{array}{l}\text { Control } \\
\text { Irradiated }\end{array}\right.$ & $\left.\begin{array}{l}1640 \\
1045\end{array}\right\}$ & $0 \cdot 65$ \\
\hline $30 \mathrm{~min}$. & $\left\{\begin{array}{l}\text { Control } \\
\text { Irradiated }\end{array}\right.$ & $\left.\begin{array}{r}1070 \\
955\end{array}\right\}$ & $0 \cdot 90$ \\
\hline $1 \mathrm{hr}$. & $\left\{\begin{array}{l}\text { Control } \\
\text { Irradiated }\end{array}\right.$ & $\left.\begin{array}{l}1405 \\
2340\end{array}\right\}$ & $1 \cdot 65$ \\
\hline $6 \mathrm{hr}$. & $\left\{\begin{array}{l}\text { Control } \\
\text { Irradiated }\end{array}\right.$ & $\left.\begin{array}{r}760 \\
1960\end{array}\right\}$ & $2 \cdot 6$ \\
\hline \multicolumn{4}{|l|}{ After $1 \mathrm{hr}$. in darkness } \\
\hline $7 \frac{1}{2} \min$. & $\left\{\begin{array}{l}\text { Control } \\
\text { Irradiated }\end{array}\right.$ & $\left.\begin{array}{r}1065 \\
634\end{array}\right\}$ & $0 \cdot 6$ \\
\hline $15 \mathrm{~min}$. & $\left\{\begin{array}{l}\text { Control } \\
\text { Irradiated }\end{array}\right.$ & $\left.\begin{array}{l}1505 \\
1805\end{array}\right\}$ & 1.2 \\
\hline $30 \mathrm{~min}$. & $\left\{\begin{array}{l}\text { Control } \\
\text { Irradiated }\end{array}\right.$ & $\left.\begin{array}{l}1207 \\
2045\end{array}\right\}$ & $1 \cdot 7$ \\
\hline $1 \mathrm{hr}$. & $\left\{\begin{array}{l}\text { Control } \\
\text { Irradiated }\end{array}\right.$ & $\left.\begin{array}{l}1100 \\
2640\end{array}\right\}$ & $2 \cdot 4$ \\
\hline
\end{tabular}

to indicate the amount of photoreactivation, it seems that $1 \mathrm{hr}$. after inoculation most of the particles in plants kept dark are in a condition in which they are susceptible to the effect of light, and that some of these then respond to exposures as short as $7.5 \mathrm{~min}$. and the majority to an exposure of $15 \mathrm{~min}$., exposures which have little or no effect when given immediately after inoculation. To get the same response as is given by $15 \mathrm{~min}$. of exposure after $1 \mathrm{hr}$. in the dark, 45 min. of exposure are needed immediately after inoculation. This means that about $\mathbf{3 0}$ min. pass after inoculation before most of the virus particles reach a state in which they become susceptible to the effects of light, a conclusion further supported by the fact that $30 \mathrm{~min}$. of exposure after $1 \mathrm{hr}$. in the dark gave approximately the same amount of photoreactivation as $1 \mathrm{hr}$. in the light immediately after inoculation. As $1 \mathrm{hr}$. in the light after $1 \mathrm{hr}$. in the dark gave almost as much photoreactivation as $6 \mathrm{hr}$. continuously in the 
light, nearly all the particles must have reached the photoreactivable stage within $2 \mathrm{hr}$. This happens, too, when the plants are in the light for $2 \mathrm{hr}$.; periods of continuous light between 1 and $6 \mathrm{hr}$. were not tested in the experiment recorded in Table 4, but they were in other experiments in which $2 \mathrm{hr}$. gave more photoreactivation than $1 \mathrm{hr}$., but 3 and $6 \mathrm{hr}$. gave only a slight additional response.

Thus the initial stages in the process of infection seem to proceed at much the same rate whether plants are kept in the light or dark, and, by combining the results of experiments such as those shown in Tables 3 and 4, three stages in the condition of infecting particles can be detected and their duration approximately timed. First, there is the stable stage of the virus particles in the inoculum, which persists for some time in inoculated leaves; a few particles move out of this stable stage within $10 \mathrm{~min}$. of being inoculated to leaves, but most need about $30 \mathrm{~min}$. and a few as long as $2-3 \mathrm{hr}$. The change to the second stage is shown by irradiated particles becoming susceptible to photoreactivation and it happens to most particles between 30 and $90 \mathrm{~min}$. after leaves are rubbed; if the inoculated plants are in the light, it probably lasts for $15 \mathrm{~min}$. or less, but if they are in the dark it can last for 1-2 hr. If, during this time, the particles fail to initiate the processes that lead to virus multiplication, they change to the third stage and lose their activity.

This sequence can profitably be compared with the results Dulbecco (1950) obtained with coli phages. He found that irradiated phage particles become susceptible to photoreactivation immediately they infect bacteria, and that the duration of this susceptible state depends on the metabolic activity of the bacterial culture. When the host cells are 'active' (conditions that favour phage multiplication) the susceptible state is brief, but it is prolonged when the bacteria are 'resting'. Plant viruses normally multiply in cells that have long ceased to divide; all our experiments were made with cells that, for this comparison, resemble metabolically 'active' rather than 'resting' bacteria. The sequence of events, then, from a state insusceptible to photoreactivation, through a transient susceptible one, is similar, the main difference being that potato virus $\mathbf{X}$ takes longer to complete each stage, which is at least partly attributable to the fact that our experiments were made at $20^{\circ}$ and those with the phage at $37^{\circ}$.

There is now much evidence that infection by coli phages entails the nucleic acid moiety separating from the protein of the phage particle and that the host bacteria are penetrated by the nucleic acid only (Hershey \& Chase, 1952). Hence, only the nucleic acid seems to be concerned in photoreactivation and the sensitive state is reached immediately the nucleic acid is in the host cell. By analogy with phage it is reasonable to assume that the period after inoculation when plant viruses cannot be photoreactivated is the time they take to enter the host cells or, perhaps, some specific component of the cells. It may, too, be the time when the nucleic acid becomes separated from the protein part of the virus particles, but there is no direct evidence that such a separation is a part of the process that leads to successful infection and multiplication by plant viruses. Some support for the idea is perhaps provided by experi- 
ments with ribonuclease, and Casterman \& Jeener (1955) suggest that this enzyme may prevent tobacco mosaic virus from multiplying in recently inoculated cells by destroying its nucleic acid. Ribonuclease has no permanent effect on plant viruses when incubated with them in vitro, but its presence in an inoculum prevents the viruses from becoming established in rubbed leaves (Loring, 1942; Kleczkowski, 1946; Bawden \& Kleczkowski, 1948). It can also interfere with the course of infection when applied to leaves shortly after they have been inoculated with viruses. We have rubbed solutions of pancreatic ribonuclease over tobacco leaves at different intervals after they were inoculated with potato virus $\mathbf{X}$ and found that this decreases the numbers of lesions up to an hour or more but has little effect after $3 \mathrm{hr}$. It may be significant that this period roughly coincides with that during which the irradiated virus can be photoreactivated, but it would be decidedly premature to draw any firm conclusions about either the behaviour of the infecting particles or the mechanism whereby ribonuclease prevents them from multiplying. Before this can be done, many more detailed experiments will be needed comparing the behaviour of ribonuclease with other inhibitors of infection that have no ability to hydrolyse ribonucleic acid, and it will be necessary to make the comparisons with plants kept in the light and dark for various periods after they have been inoculated with irradiated and normal virus preparations. That ribonuclease may act by affecting the host plants, rather than by destroying the virus or a part of it, is suggested by the fact that the extent to which it decreases numbers of lesions depends on the species of host plant inoculated; but this again is inconclusive, for conditions in cells of some species may be more conducive than in others for enzyme activity. Work with a Rhizobium phage also provides evidence for an effect on the host cell (Kleczkowski \& Kleczkowski, 1954). The multiplication of this phage, which probably contains no ribonucleic acid, is not only inhibited when phage, bacteria and ribonuclease are present simultaneously, but when the bacterial cells are first incubated with the enzyme alone and then freed from it before the phage is added.

The fate of the phage nucleic acid that is not photoreactivated in 'active' bacteria is unknown, but such bacteria contain nucleases, which can reasonably be assumed to digest it. Similarly, plant cells contain nucleases and proteases, and, although these do not hydrolyse most plant viruses in vitro, they may be able to hydrolyse them in vivo after they have changed to the state in which irradiated particles become susceptible to photoreactivation.

\section{Light intensity and duration of exposure}

We have not studied the interaction between intensity of light and the length of exposure necessary to give photoreactivation in any detail, but have a few relevant observations. Most of our experiments were done in daylight, usually in cloudy weather when the light intensity in the glasshouses was c. 600 f.c. Exposure to this for $15 \mathrm{~min}$. seems enough to activate all particles which have reached the state in cells when they can respond to light, and exposures when the sun shone and the light intensity in the glasshouses was 
c. 2000 f.c. gave no more photoreactivation than did 600 f.c. In only one experiment have we compared artificial light of different intensities, when inoculated plants which had spent an hour in the dark were then given various lengths of time at either 600 or 80 f.c. before again being put in the dark. Twenty minutes in the weaker light gave some photoreactivation and the amount was not increased by prolonging the exposure to $2 \mathrm{hr}$.; it was less than that given by $10 \mathrm{~min}$. exposure to the brighter light. The results suggest that irradiated particles may differ in the intensity of light needed to reactivate them, and that prolonged exposure to weak light does not have any cumulative effect comparable to brief exposures to bright light, but more critical experiments would be needed to establish the point.

\section{Relative stability of radiated and un-irradiated virus}

Exposure of preparations of a Rhizobium bacteriophage (Kleczkowski \& Kleczkowski, 1953) or of chymotrypsin (Kleczkowski, 1954a) to ultraviolet radiation decreases their stability, and irradiated preparations lose their residual activity more rapidly than do comparably treated un-irradiated ones. We could not detect such a phenomenon with tobacco mosaic, tobacco necrosis or tomato bushy stunt viruses (Bawden \& Kleczkowski, 1953), but these are exceptionally stable viruses and neither the control nor irradiated preparations lost any activity over the period in which they were stored. Potato virus $\mathbf{X}$ is less stable and, when stored at $2^{\circ}$ in $\mathrm{M} / 15$-phosphate buffer $(\mathrm{pH} 7)$, loses about $90 \%$ of its infectivity in a week. We could, however, find no evidence that irradiation increases the instability. Table 5 shows that irradiated and control preparations lost approximately the same proportion of their infectivity when stored in these conditions, and photoreactivation was as pronounced 8 days after irradiation as immediately afterwards.

Table 5. The relative stability of irradiated and un-irradiated preparations of potato virus $X$

\begin{tabular}{|c|c|c|}
\hline \multirow[b]{2}{*}{ Inoculum } & \multicolumn{2}{|c|}{ Lesions produced on plants kept in } \\
\hline & $\begin{array}{c}\text { Darkness after } \\
\text { inoculation }\end{array}$ & $\begin{array}{l}\text { Light after } \\
\text { inoculation }\end{array}$ \\
\hline $\begin{array}{l}\text { Control, fresh sap } \\
\text { Irradiated fresh sap }\end{array}$ & $\left.\begin{array}{r}1200 \\
400\end{array}\right\} R=0 \cdot 35$ & $\left.\begin{array}{r}590 \\
1400\end{array}\right\} R=2 \cdot 4$ \\
\hline $\begin{array}{l}\text { Control, stored sap } \\
\text { Stored irradiated sap }\end{array}$ & $\left.\begin{array}{r}129 \\
55\end{array}\right\} R=0 \cdot 4$ & $\left.\begin{array}{r}48 \\
145\end{array}\right\} R=3 \cdot 0$ \\
\hline
\end{tabular}

Virus irradiated as infective sap diluted $1 / 10$ with phosphate buffer, $\mathrm{pH} 7$, and stored for 8 days at $2^{\circ}$ in this condition. Control was also stored as sap diluted $1 / 10$. Before inoculation the control solutions were diluted a further $1 / 200$ with buffer and the irradiated solution $\frac{1}{2}$. $R=$ ratio of numbers of lesions produced by irradiated virus to those produced by the control.

\section{Inactivation as a function of the amount of energy absorbed}

McLaren, Gentile, Kirk \& Levin (1953) found that the quantum yields for the inactivation of various enzymes by ultraviolet radiation, when multiplied by their molecular weights, do not differ much from a mean value of 447 ; 
Kleczkowski $(\mathbf{1 9 5 4} b)$ found that this was also true with antibodies. Put another way, this means that, if inactivation follows a first-order reaction, the same amount of energy must be absorbed per unit weight of any of these proteins to decrease their specific activities by a given fraction. For example, to halve the original activity of a milligram of any one requires about 0.75 joule of energy at $\lambda=\mathbf{2 5 3 7} \mathrm{A}$.

It seems that this rule does not apply to plant viruses. McLaren et al. (1953) found that the quantum yield of tobacco mosaic virus was too high, and it is much more resistant to inactivation by ultraviolet radiation than potato virus $\mathbf{X}$, even when inoculated plants are kept in the light, and putting inoculated plants in the dark increases its quantum yield by a further factor of about three. The quantum yield of potato virus $\mathbf{X}$ cannot be estimated at all accurately, for the estimation requires knowledge of the particle size, and its filamentous particles vary enormously in length. Fortunately, to find how far the virus deviates from the rule which applies to enzymes and antibodies, the quantum yield need not be estimated, but only the amount of energy needed to halve the infectivity of a milligram of purified virus. Even this measurement will not be accurate, for measurements with the spectrophotometer do not distinguish between energy absorbed and scattered, and virus particles are large enough to scatter much of the incident ultraviolet radiation. Thus the viruses will absorb considerably less than the amount measured and their sensitivity to inactivation will seem less than it really is.

Our measurements were made on purified viruses diluted in $\mathbf{M} / 15$-phosphate buffer ( $\mathrm{pH} \mathrm{7),} \mathrm{conditions} \mathrm{in} \mathrm{which} \mathrm{four} \mathrm{strains} \mathrm{of} \mathrm{tobacco} \mathrm{mosaic} \mathrm{virus} \mathrm{and}$ potato virus $\mathrm{X}$ all give the same extinction coefficient. Preparations of potato virus $\mathbf{X}$ in water give higher extinction coefficients, sometimes twice as great, because the particles aggregate in distilled water and consequently scatter more energy. The total energy, absorbed and scattered by $0.02 \%(\mathrm{w} / \mathrm{v})$ solutions of virus, needed per milligram to halve the infectivity is 0.02 joule for potato virus $\mathrm{X}$ when inoculated plants are placed in the dark and about 0.06 joule when they are placed in the light; for the U2 strain of tobacco mosaic virus it is 0.065 joule, and it is 0.15 joule for $U 1$, the Rothamsted stock strain and the Datura strain. The actual amount of energy absorbed is perhaps only half that measured, but even without taking this into consideration it is quite clear that they all fall far short of the $\mathbf{0 . 7 5}$ joule needed to halve the activity of the other proteins. Even the resistant strains of tobacco mosaic virus need about one-fifth the amount predicted by the rule for other proteins, U2 about one-twelfth and potato virus $X$ from $1 / 12$ th to $1 / 40$ th, depending on whether the inoculated plants are placed in the light or dark. It is reasonable to assume that this greater sensitivity to ultraviolet radiation reflects the fact that the viruses contain nucleic acid and that changes in the nucleic acid directly affect the processes leading to virus multiplication. If this is so, then it seems that the nucleic acids of different viruses, and of different strains of tobacco mosaic virus, must differ in their sensitivity to inactivation by ultraviolet radiation, for the five purified preparations we used all had the same total amount of nucleic acid. 


\section{REFERENCES}

Bawden, F. C. \& KLeczkowski, A. (1948). Variations in the properties of potato virus $\mathrm{X}$ and their effects on its interactions with ribonuclease and proteolytic enzymes. J. gen. Microbiol. 2, 173.

Bawden, F. C. \& Kleczkowski, A. (1952). Ultra-violet injury to higher plants counteracted by visible light. Nature, Lond. 169, 90.

Bawden, F. C. \& Kleczkowski, A. (1953). The behaviour of some plant viruses after exposure to ultraviolet radiation. J. gen. Microbiol. 8, 145.

Bawden, F. C. \& Roberts, F. M. (1948). Photosynthesis and predisposition of plants to infection with certain viruses. Ann. appl. Biol. 35, 418.

Casterman, C. \& Jeener, R. (1955). Sur le mécanisme de l'inhibition par la ribonucléase de la multiplication du virus de la mosaiqque du tabac. Biochim. Biophys. Acta, 16, 433.

Dulbecco, R. (1950). Experiments on photoreactivation of bacteriophages inactivated by ultraviolet radiation. J. Bact. 59, 329.

Ginoza, W., Atrinson, D. E. \& Wildman, S. G. (1954). A differential ability of tobacco mosaic virus to bind host-cell nucleoprotein. Science, 119, 269.

Hershey, A. D. \& Chase, M. (1952). Independent functions of viral protein and nucleic acid in growth of bacteriophage. J. gen. Physiol. 36, 39.

Kelner, A. (1949). Photoreactivation of ultraviolet-treated Escherichia coli, with special reference to the dose-reduction principle and the ultraviolet-induced mutations. J. Bact. 58, 511.

KeLner, A. (1951). Action spectra for photoreactivation of ultraviolet-irradiated Escherichia coli and Streptomyces griseus. J. gen. Physiol. 34, 835.

KLECzkowski, A. (1946). Combination between different proteins and between proteins and yeast nucleic acid. Biochem. J. 40, 677 .

KLECZKowski, A. (1954a). Stability of chymotrypsin and tobacco mosaic virus decreased by ultraviolet radiation. Biochem. J. 56, 345.

KLeczkowski, A. (1954b). Inactivation of antibodies by ultraviolet radiation. Brit. J. exp. Path. 35, 402.

KLeczkowski, J. \& KLeCzkowski, A. (1953). The behaviour of Rhizobium bacteriophages during and after exposure to ultraviolet radiation. J.gen. Microbiol. 8, 135.

KLeczkowski, J. \& Kueczkowski, A. (1954). The effect of ribonuclease on phagehost interaction. J. gen. Microbiol. 11, 451.

Lorivg, H. S. (1942). The reversible inactivation of tobacco mosaic virus by crystalline ribonuclease. J. gen. Physiol. 25, 497.

Mclaren, A. D., Gentile, P., Krrk, D. \& Levin, N. A. (1953). Photochemistry of proteins. XVII. Inactivation of enzymes with ultraviolet light and photolysis of the peptide bond. J. Polym. Sci. 10, 333.

(Received 7 April 1955) 